\title{
Pengaruh Peristiwa Politik (Pemilu Presiden dan Pengumuman Susunan Kabinet) Terhadap Saham Sektor Industri Di Bursa Efek Indonesia
}

\author{
Siti Wardani Bakri Katti \\ ${ }^{1}$ Fakultas Ekonomi, Universitas Merdeka Madiun \\ email: sitiwardani@unmer-madiun.ac.id
}

\begin{abstract}
Political events is one of the non-economic risks that may affect the investor's decision to invest in the capital market. The purpose of this article to determine the reaction and the difference of abnormal return of stock industry sector in Indonesia Stock Exchange (IDX) between before and after the political events (the presidential elections and the announcement of the cabinet line). Selection of industrial sector companies as research objects based on the premise that the industrial sector is the main sector driving stock trading in the IDX. This article using event study method to measure the market's reaction to events of national politics. In conducting this article used the data Composite Stock Price Index (JCI) as well as daily stock trading data on the industrial sector. Based on the results of the sample selection using purposive sampling, the sample in the study of 40 companies. The results can be concluded that there are abnormal returns around the national political events, but there are no differences in Average Abnormal Return (AAR) before and after the political events. This shows the predictions and information received by the stock market participants are relatively the same.
\end{abstract}

Keywords: Political Events, Presidential Elections, Stock Market, Abnormal Return, Event Study

\begin{abstract}
ABSTRAK
Peristiwa politik merupakan salah satu risiko non-ekonomi yang dapat mempengaruhi keputusan investor untuk berinvestasi di pasar modal. Tujuan artikel ini untuk mengetahui reaksi dan perbedaan abnormal return saham sektor industri di Bursa Efek Indonesia (BEI) antara sebelum dan sesudah peristiwa politik (pemilihan umum presiden dan pengumuman susunan kabinet). Pemilihan perusahaan sektor industri sebagai objek penelitian berdasarkan pemikiran bahwa sektor industri merupakan sektor utama yang mendorong perdagangan saham di BEI. Artikel ini menggunakan metode event study untuk mengukur reaksi pasar terhadap peristiwa politik nasional. Dalam melakukan artikel ini digunakan data Indeks Harga Saham Gabungan (IHSG) serta data perdagangan saham harian pada sektor industri. Berdasarkan hasil seleksi sampel menggunakan metode purposive sampling, sampel dalam penelitian sebanyak 40 perusahaan. Hasil penelitian dapat disimpulkan bahwa ada abnormal return di seputar peristiwa politik nasional, namun tidak ada perbedaan Average Abnormal Return (AAR) sebelum dan sesudah peristiwa politik. Hal ini menunjukkan prediksi dan informasi yang diterima oleh pelaku pasar saham relatif sama.
\end{abstract}

Kata Kunci: Kata Kunci: Peristiwa Politik, Pemilu Presiden, Pasar Modal, Abnormal Return, Event Study 


\section{PENDAHULUAN}

Aktivitas pasar modal yang dinamis di suatu negara akan menggambarkan begitu baiknya kondisi iklim bisnis di negara yang bersangkutan. Kinerja pasar modal yang baik merupakan barometer bagi sehatnya perekonomian yang akan menimbulkan kegairahan investor untuk kembali berinvestasi (Tandelilin, 2010), dimana indeks merupakan cerminan pergerakan harga saham di pasar modal. Oleh karena itu, arah dan besarnya perubahan indeks di pasar modal menjadi salah satu tolak ukur bagi investor dalam rangka menanamkan modalnya di pasar modal.

Tujuan investor dalam berinvestasi adalah memaksimalkan return, tanpa melupakan faktor risiko investasi yang harus dihadapinya. Ada beberapa sumber risiko yang bisa mempengaruhi besarnya risiko suatu investasi, antara lain risiko pasar, risiko suku bunga, risiko inflasi, risiko likuiditas, risiko politik, dan lain sebagainya.

Peristiwa-peristiwa politik merupakan salah satu risiko non-ekonomi yang dapat berpengaruh pada keputusan investor dalam berinvestasi di pasar modal, karena situasi politik suatu negara pada dasarnya berpengaruh pada kondisi perekonomian negara tersebut.

Peristiwa politik seperti pemilihan umum pergantian kepala negara dan penyusunan Kabinet Kerja yang baru adalah beberapa peristiwa politik yang menarik untuk diteliti karena hanya terjadi lima tahun sekali. Salah satu peristiwa yang menarik untuk diuji kandungan informasinya adalah peristiwa Pemilihan Umum tahun 2014. Pengujian kandungan informasi peristiwa Pemilihan Umum tahun 2014 terhadap aktivitas bursa efek ini dimaksudkan untuk melihat reaksi pasar yang dapat diukur dengan menggunakan abnormal return.

Berdasarkan uraian tersebut, maka peneliti mencoba melakukan penelitian dengan metode event study mengenai kaitan antara peristiwa politik nasional dengan pergerakan harga saham di bursa efek, dengan mengangkat judul: "Pengaruh peristiwa pemilu presiden dan pengumuman susunan kabinet terhadap saham sektor industri di bursa efek Indonesia”.

Permasalahan dalam penelitian ini adalah "Apakah peristiwa politik 
(pemilu presiden dan pengumuman susunan kabinet) yang terjadi, direaksi oleh pasar yang ditunjukkan dengan adanya abnormal return yang signifikan pada perdagangan saham sektor industri?"

Tujuan dari penelitian ini adalah, untuk mengetahui reaksi dari perdagangan saham sektor industri di Bursa Efek Indonesia terhadap terjadinya peristiwa politik (pemilu presiden dan pengumuman susunan kabinet).

\section{METODE PENELITIAN}

\section{Periode Pengamatan}

Periode penelitian dengan teknik event study terdiri dari 2 periode waktu menurut Konchitchki dan O'Leary (2011 dalam Anggarani 2012), yaitu periode estimasi (estimation period) dan periode peristiwa (event period).

Tanggal suatu peristiwa dipublikasikan untuk pertama kali ditetapkan sebagai event day $\left(\mathrm{t}_{0}\right)$. Apabila tanggal tersebut adalah hari libur bagi kegiatan perdagangan saham, maka tanggal perdagangan yang terdekat berikutnya ditetapkan sebagai event day. Batasan rentang waktu penelitian menurut Lako (dalam
Anggarani, 2012), periode peristiwa (event period) yang diambil adalah dari tujuh hari (seminggu) perdagangan saham sebelum terjadinya peritiwa $\left(\mathrm{t}_{-7}\right)$ hingga tujuh hari perdagangan saham setelah terjadinya peristiwa $\left(t_{+7}\right)$. Dan untuk periode estimasi diambil dari 30 hari (satu bulan) sebelum terjadinya peristiwata $\left(\mathrm{t}_{-30}\right)$. Rentang waktu tersebut dipilih karena reaksi pasar sudah dapat terlihat selama rentang waktu tersebut. Pada periode tersebut diharapkan pasar telah menyerap semua informasi yang berkembang seputar peris-tiwa yang terjadi.

Masing-masing jangka waktu pengamatan ini terbagi lagi ke dalam dua periode pengamatan, yaitu: periode estimasi (estimation period) dan periode peristiwa (event period). Periode estimasi dimanfaatkan untuk menghitung imbal hasil saham dari sampel dalam keadaan normal. Yang dimaksud dengan keadaan normal adalah tidak terjadi suatu peristiwa tertentu yang berpengaruh terhadap sampel saham pada periode estimasi. Periode peristiwa dimanfaatkan untuk menghitung abnormal return dari sampel pada saat peristiwa berlangsung (Manurung dan Cahyanti, 
2007). Periode ini merupakan periode di dekat peristiwa tersebut terjadi. Rentang event period yang digunakan untuk penelitian ini selama 7 hari (satu minggu).

Tabel berikut ini menyajikan estimation period dan event period untuk masing-masing peristiwa.

Tabel 1

Estimation Period dan Event Period

\begin{tabular}{|l|c|c|c|c|}
\hline \multirow{2}{*}{ Peristiwa } & $\begin{array}{c}\text { Estimat } \\
\text { ion } \\
\text { Period }\end{array}$ & \multicolumn{4}{|c|}{ Event Period } \\
\cline { 2 - 5 } & $\mathrm{t}_{-30}$ & $\mathrm{t}_{-7}$ & $\mathrm{t}_{0}$ & $\mathrm{t}_{+7}$ \\
\hline $\begin{array}{l}\text { Pemilu } \\
\text { Presiden dan } \\
\text { Wakil Presiden }\end{array}$ & $14 / 05 / 1$ & $30 / 06 / 1$ & $10 / 07 /$ & $21 / 07 / 1$ \\
2014 & 4 & 14 & 4 \\
\hline $\begin{array}{l}\text { Pengumuman } \\
\text { Susunan }\end{array}$ & $04 / 09 / 1$ & $16 / 10 / 1$ & $27 / 10 /$ & $05 / 11 / 1$ \\
Kabinet Kerja & 4 & 4 & 14 & 4 \\
2014 & & & & 4 \\
\hline
\end{tabular}

\section{Data, Jenis dan Lokasi Penelitian}

Penelitian ini menggunakan metode studi peristiwa (event study) dalam mengukur reaksi pasar terhadap peristiwa politik nasional. Event Study merupakan studi yang mempelajari reaksi pasar terhadap suatu peristiwa (event) yang informasinya dipublikasikan sebagai suatu pengumuman. Event study dapat digunakan untuk menguji kandungan informasi (information content) dari suatu pengumuman dan dapat juga digunakan untuk menguji efisiensi pasar (Jogiyanto, 2007).

Jenis data yang digunakan dalam penelitian ini adalah data sekunder, yaitu data yang dikumpulkan oleh pihak lain dan bersifat time series. Dalam melakukan penelitian ini dipergunakan data Indeks Harga Saham Gabungan (IHSG) serta data perdagangan saham harian pada sektor industri. Adapun sumber data dalam penelitian ini didapat melalui Galeri Investasi Universitas Islam Indonesia Yogyakarta.

\section{Populasi dan Sampel}

Populasi dalam penelitian ini adalah keseluruhan dari obyek penelitian yang akan diteliti yaitu perusahaanperusahaan pada sektor industri di Bursa Efek Indonesia.

Metode pemilihan atau pengambilan sampel dalam penelitian ini menggunakan teknik purposive sampling, yaitu teknik pemilihan atau pengambilan sampel dengan pertimbangan-pertimbangan dan kriteria tertentu. Adapun kriteria pengambilan sampel dari penelitian ini adalah sebagai berikut: 
1) Emiten-emiten yang dijadikan sampel merupakan emiten pada sektor industri yang sahamnya aktif diperdagangkan, yaitu saham -saham yang memiliki volume transaksi lebih besar daripada nol pada saat peristiwa tersebut berlangsung (event day).

2) Saham-saham tersebut telah terdaftar di BEI selama periode estimasi. Pengambilan saham-saham yang aktif diperdagangkan pada saat peristiwa berlangsung sebagai sampel pada penelitian ini didasari oleh pertimbangan bahwa investor akan bereaksi terhadap informasi yang muncul pada saat sebuah peristiwa terjadi dengan melakukan transaksi terhadap saham-saham yang ada di Bursa Efek Indonesia.

Berdasarkan hasil pemilihan sampel dengan metode purposive sampling, yang akan menjadi sampel dalam penelitian sebanyak 40 perusahaan dari 134 perusahaan pada sektor industri yang terdaftar di Bursa Efek Indonesia.

\section{Metode Analisis Data}

Alat analisis dan model perhitungan return saham yang digunakan dalam penelitian ini adalah pengujian abnormal return. Pengolahan dan perhitungan data dilakukan dengan menggunakan program Microsoft Excel, EViews Versi 9 (Econometric Views) dan SPSS Versi 20.0. Tahaptahap pengujian abnormal return berdasarkan metode event study (Hartono, dalam Trisnawati, 2013), adalah:

1) Menentukan sampel.

2) Mengidentifikasi hari pengumuman atau event day, yaitu pada peristiwa pemilu presiden dan wakil presiden pada tanggal 9 Juli 2014 dan pengumuman susunan Kabinet Kerja pada tanggal 26 Oktober 2014.

3) Menentukan periode penelitian termasuk periode estimasi (estimation period) dan periode peristiwa (event period).

4) Menghitung return realisasi atau return aktual (actual return) yaitu return yang telah terjadi pada masing-masing sampel setiap hari selama periode pengamatan dengan rumus:

$$
\mathrm{R}_{\mathrm{i}, \mathrm{t}} \quad=\mathrm{P}_{\mathrm{i}, \mathrm{t}}-\mathrm{P}_{\mathrm{i}, \mathrm{t}} / \mathrm{P}_{\mathrm{i}, \mathrm{t}-1}
$$

5) Menghitung market return (return pasar) per hari selama periode peristiwa, menggunakan rumus : 
$\mathrm{Rm}_{\mathrm{t}}=\mathrm{IHSG}_{\mathrm{t}}-\mathrm{IHSG}_{\mathrm{t}-1} / \mathrm{IHSG}_{\mathrm{t}-1}$

6) Menghitung return dari saham perusahaan selama periode peristiwa menggunakan model pasar (market model), sedangkan model ekspektasi dapat dibentuk dengan menggunakan teknik regresi OLS (Ordinary Least Square) antara actual return dengan market return selama estimation period (Tandelilin, 2010: 574) dengan model sebagai berikut :

$$
\mathrm{E}\left(\mathrm{R}_{\mathrm{i}, \mathrm{t}}\right)=\alpha_{\mathrm{i}, \mathrm{t}}+\beta \mathrm{iRm}_{\mathrm{t}}
$$

7) Menghitung abnormal return dalam penelitian ini diartikan sebagai selisih dari imbal hasil aktual (actual return) yang didapatkan investor pada saat terjadinya sebuah peristiwa (realized return) dengan imbal hasil yang diharapkan investor jika tidak terjadi peristiwa tersebut (expected return). Secara matematis abnormal return tersebut dinyatakan sebagai berikut:

$$
\mathrm{AR}_{\mathrm{i}, \mathrm{t}}=\mathrm{R}_{\mathrm{i}, \mathrm{t}}-\mathrm{E}\left(\mathrm{R}_{\mathrm{i}, \mathrm{t}}\right)
$$

8) Menghitung Average Abnormal Return (AAR) seluruh saham untuk masing-masing hari selama event period. Average Abnormal Return (AAR) digunakan untuk melihat respon pasar harian selama event period ( $\mathrm{t}_{-7}$ sampai dengan $t_{+7}$ ). Adapun rumus perhitungan Average Abnormal Return (AAR) sebagai berikut:

$$
A A R t=\frac{\sum_{i=1}^{n} \text { ARi.t }}{n}
$$

9) Uji Beda t

Pengujian statistik dilakukan dengan menggunakan uji beda dengan membandingkan nilai $\mathrm{t}$ hitung dengan nilai t-statistik yang terdapat dalam tabel statistik.

\section{HASIL DAN PEMBAHASAN}

Peristiwa Pemilu Presiden

Tabel 2

Uji Signifikansi Return Tak

Normal (Abnormal Return)

\begin{tabular}{|c|c|c|c|c|c|c|}
\hline TANGGAL & $\mathbf{T}$ & $\mathbf{A R}$ & $\mathbf{A A R}$ & $\begin{array}{c}t \\
\text { hitung }\end{array}$ & t tabel & Ket. \\
\hline 30-Jun-14 & -7 & -0.0371 & -0.0009 & -0.2114 & 2.1448 & $\begin{array}{c}\text { Tdk } \\
\text { Signifikan }\end{array}$ \\
\hline 1-Jul-14 & -6 & 0.0679 & 0.0017 & 0.9956 & 2.1448 & $\begin{array}{c}\text { Tdk } \\
\text { Signifikan }\end{array}$ \\
\hline 2-Jul-14 & -5 & 0.2981 & 0.0075 & 6.0703 & 2.1448 & Signifikan \\
\hline 3-Jul-14 & -4 & 0.1127 & 0.0028 & 1.5303 & 2.1448 & $\begin{array}{c}\text { Tdk } \\
\text { Signifikan }\end{array}$ \\
\hline 4-Jul-14 & -3 & 0.4174 & 0.0104 & 4.7676 & 2.1448 & Signifikan \\
\hline 7-Jul-14 & -2 & 0.0095 & 0.0002 & 0.5098 & 2.1448 & $\begin{array}{c}\text { Tdk } \\
\text { Signifikan }\end{array}$ \\
\hline 8-Jul-14 & -1 & 0.2490 & 0.0062 & 1.9485 & 2.1448 & $\begin{array}{c}\text { Tdk } \\
\text { Signifikan }\end{array}$ \\
\hline 10-Jul-14 & 0 & 3.2648 & 0.0816 & 43.8844 & 2.1448 & Signifikan \\
\hline 11-Jul-14 & +1 & 2.0698 & 0.0518 & 25.2806 & 2.1448 & Signifikan \\
\hline 14-Jul-14 & +2 & 0.1542 & 0.0039 & 1.6926 & 2.1448 & $\begin{array}{c}\text { Tdk } \\
\text { Signifikan }\end{array}$ \\
\hline 15-Jul-14 & +3 & 0.5669 & 0.0142 & 8.6698 & 2.1448 & Signifikan \\
\hline 16-Jul-14 & +4 & 0.2768 & 0.0069 & 4.0909 & 2.1448 & Signifikan \\
\hline
\end{tabular}

Peristiwa Pemilu Presiden dan

Wakil Presiden Pada Event Period 
Dari tabel diatas, dapat diketahui bahwa pada 8 hari bursa pada event period terjadi rata-rata abnormal return yang signifikan. Signifikansi rata-rata abnormal return yang terjadi sebelum dan setelah peristiwa menunjukkan adanya reaksi yang baik dari para investor (pelaku pasar modal) atas kemenangan Calon Presiden Joko Widodo dan Wakil Presiden Jusuf Kalla.

Hasil pengujian ini sama seperti hasil penelitian yang dilakukan oleh Permana, Mahadwartha, dan Sutejo (2013) yang menunjukkan adanya perbedaan abnormal return positif yang signifikan terhadap terjadinya peristiwa pilkada Gubernur DKI Jakarta pada September 2012. Selain itu, penelitian Anggarani (2012) menemukan bahwa terdapat abnormal return yang signifikan pada pemilu tahun 1999, 2001, 2004 namun tidak signifikan pada tahun 2009 sehingga kondisi pasar modal Indonesia tergolong setengah kuat (semi strong form).

\section{Peristiwa Pengumuman Susunan Kabinet}

Hasil uji signifikansi return peristiwa susunan kabinet:
Tabel 3

Uji Signifikansi Return Tak Normal (Abnormal Return) Peristiwa Pengumuman Susunan Kabinet Pada Event Period $\left(t_{-7}\right.$ sampai $\left.t_{+7}\right)$

\begin{tabular}{|c|c|c|c|c|c|c|}
\hline TANGGAL & $\mathbf{T}$ & $\mathbf{A R}$ & AAR & $\begin{array}{c}t \\
\text { hitung }\end{array}$ & t table & KET. \\
\hline 16-Oct-14 & -7 & 0.0050 & 0.0001 & 0.6630 & 2.1448 & $\begin{array}{c}\text { Tdk } \\
\text { Signifikan }\end{array}$ \\
\hline 17-Oct-14 & -6 & 0.0274 & 0.0007 & 1.4683 & 2.1448 & $\begin{array}{c}\text { Tdk } \\
\text { Signifikan }\end{array}$ \\
\hline 20-Oct-14 & -5 & 0.0286 & 0.0007 & 0.5001 & 2.1448 & $\begin{array}{c}\text { Tdk } \\
\text { Signifikan }\end{array}$ \\
\hline 21-Oct-14 & -4 & -0.2896 & -0.0072 & -3.5458 & 2.1448 & $\begin{array}{c}\text { Tdk } \\
\text { Signifikan }\end{array}$ \\
\hline 22-Oct-14 & -3 & 0.1189 & 0.0030 & 1.6328 & 2.1448 & $\begin{array}{c}\text { Tdk } \\
\text { Signifikan }\end{array}$ \\
\hline 23-Oct-14 & -2 & 0.0713 & 0.0018 & 0.9489 & 2.1448 & $\begin{array}{c}\text { Tdk } \\
\text { Signifikan }\end{array}$ \\
\hline 24-Oct-14 & -1 & 0.3851 & 0.0096 & 3.5260 & 2.1448 & Signifikan \\
\hline 27-Oct-14 & $\mathbf{0}$ & 1.8226 & 0.0456 & 19.0212 & 2.1448 & Signifikan \\
\hline 28-Oct-14 & +1 & 0.7127 & 0.0178 & 7.0189 & 2.1448 & Signifikan \\
\hline 29-Oct-14 & +2 & 0.2161 & 0.0054 & 2.8683 & 2.1448 & Signifikan \\
\hline 30-Oct-14 & +3 & 0.0707 & 0.0018 & 0.7888 & 2.1448 & $\begin{array}{c}\text { Tdk } \\
\text { Signifikan }\end{array}$ \\
\hline 31-Oct-14 & +4 & 0.0045 & 0.0001 & 0.9153 & 2.1448 & $\begin{array}{c}\text { Tdk } \\
\text { Signifikan }\end{array}$ \\
\hline 3-Nov-14 & +5 & -0.1356 & -0.0034 & -1.0593 & 2.1448 & $\begin{array}{c}\text { Tdk } \\
\text { Signifikan }\end{array}$ \\
\hline 4-Nov-14 & +6 & 0.0844 & 0.0021 & 1.3263 & 2.1448 & $\begin{array}{c}\text { Tdk } \\
\text { Signifikan }\end{array}$ \\
\hline 5-Nov-14 & +7 & 0.1118 & 0.0028 & 1.0553 & 2.1448 & $\begin{array}{c}\text { Tdk } \\
\text { Signifikan }\end{array}$ \\
\hline
\end{tabular}

Dari Tabel 3 diatas, dapat diketahui bahwa pada 4 hari bursa pada periode peristiwa, terjadi ratarata abnormal return yang signifikan pada tingkat $5 \%$ atau lebih besar dari 2.1448 yaitu pada $\mathrm{t}_{-1}, \mathrm{t}_{0}, \mathrm{t}_{+1}$ dan $\mathrm{t}_{+2}$. Signifikansi rata-rata abnormal return yang terjadi sebelum periode 
peristiwa yaitu $\mathrm{t}_{-1}$ menunjukkan bahwa sudah ada kebocoran informasi dari pengumuman susunan Kabinet Kerja dari Preside terpilih Joko Widodo. Pada $t_{0}, t_{+1}$, dan $t_{+2}$ pasar bereaksi dan terjadi abnormal return yang merupakan efek dari pengumuman susunan Kabinet Kerja yang dilakukan oleh Presiden Joko Widodo. Pada $t_{+3}$ sampai $t_{+7}$, pengujian abnormal return tidak signifikan. Artinya, pasar secara keseluruhan telah menyerap informasi dari pengumuman tersebut sehingga tidak terjadi lagi abnormal return. Informasi mengenai calon menteri pada susunan Kabinet Kerja sudah dapat diduga dari isu serta tanda-tanda awal dari berbagai sumber terpercaya mengenai nama para calon menteri yang akan menduduki jabatan sebagai menteri pada Kabinet Kerja. Pasar modal sudah semakin sensitif dalam merespon peristiwa-peristiwa politik yang terjadi, termasuk merespon setiap kebijakan politik. Dari hasil penelitian terhadap pengumuman susunan Kabinet Kerja dapat diketahui bahwa pasar bereaksi, namun secara informasi, pasar tidak efisien dalam bentuk setengah kuat.

\section{SIMPULAN}

Berdasarkan hasil pengujian dan analisis dari data sampel yang diperoleh, dapat diambil beberapa kesimpulan dalam penelitian ini, yaitu:

1. Pasar modal Indonesia (dalam hal ini Bursa Efek Indonesia) bereaksi terhadap peristiwa-peristiwa politik nasional yang terjadi. Hal ini dibuktikan dengan adanya abnormal return yang signifikan di seputar periode peristiwa. Hal ini menunjukkan bahwa peristiwa politik nasional yang terjadi mempunyai information content yang cukup berharga bagi pasar modal Indonesia.

2. Pada peristiwa pemilu presiden 2014, pasar modal memberikan respon positif selama 5 hari bursa pada periode peristiwa setelah terjadinya peristiwa pemilu presiden tersebut. Respon positif ini ditunjukkan dengan adanya abnormal return positif yang signifikan pada $t_{0}$ sampai dengan $t_{+7}$. Peristiwa pemilu presiden 2014 ini direspon positif oleh investor karena reputasi dari calon presiden dan calon wakil presiden Jokowi-Jusuf Kalla yang terpilih memiliki reputasi yang bagus 
dalam membuat perubahan pada kota atau provinsi yang pernah dipimpinnya. Dengan terpilihnya pasangan Jokowi-Jusuf Kalla, maka investor (pelaku pasar) mengharapkan terjadinya perubahan yang membawa perekonomian Indonesia menjadi lebih baik dan maju. Abnormal return yang signifikan pada peristiwa Pengumuman Hasil Pemilihan Presiden dihasilkan tepat pada event day $\left(t_{0}\right)$ serta $t_{+1}, t_{+3}, t_{+4}, t_{+6}$, dan $t_{+7}$. Hal ini dimungkinkan karena pemilihan presiden hanya berlangsung satu putaran dan juga telah dilakukan estimasi hasil perhitungan suara melalui metode quick count yang reliabilitasnya telah terbukti pada Pemilu Legislatif.

3. Signifikansi rata-rata abnormal return yang terjadi sebelum dan setelah periode peristiwa pengumuman susunan kabinet dari $\mathrm{t}_{-1}$ sampai $t_{+2}$ menunjukkan bahwa sudah ada kebocoran informasi dari pengumuman susunan kabinet kerja. Hal ini berarti pasar modal secara keseluruhan telah menyerap informasi dari pengumuman tersebut sehingga tidak terjadi lagi signifikan abnormal return setelah 3 hari peristiwa tersebut terjadi. Pasar modal sendiri sudah semakin sensitif dalam merespon peristiwa- peristiwa politik nasional yang terjadi, termasuk merespon setiap kebijakan politik dibawah pemerintahan yang dipimpin oleh Jokowi.

\section{DAFTAR RUJUKAN}

Anggarani, D. A. (2012). Analisis Pengaruh Kondisi Politik Dalam Negeri Terhadap abnormal return indeks LQ45 (Studi Kasus Pergantian Kepemimpinan DI Indonesia Tahun 1999, 2001, 2004, dan 2009). Tesis. Program Pascasarjanan Universitas Indonesia, Depok.

Jogiyanto, H.M. 2007. Teori Portofolio dan Analisis Investasi, Edisi 3. BPFE. Yogyakarta.

Manurung, A., \& Cahyanti, I. (2007). Pengaruh Peristiwa Politik (Pengumuman Hasil Pemilu Legislatif, Pengumuman Hasil Pemilihan Presiden, Pengumuman Susunan Kabinet, Reshuffle Kabinet) terhadap Sektor-Sektor Industri di Bursa Efek Jakarta. Jurnal Bisnis Dan Manajemen, Vol.7 No.2 Hal:135-146, November 2007. Program MM UNS, Surakarta.

Permana, H. T., dkk. (2013). Perbedaan Abnormal Return pada Sektor Keuangan Sebelum dan Sesudah Peristiwa Pilkada Gubernur DKI Jakarta 20 September 2012. Jurnal Ilmiah 
Mahasiswa Universitas Surabaya, Vol.2 No. 1. P3M Universitas Surabaya. Surabaya.

Tandelilin, E. (2010). Analisis Investasi dan Manajemen Portofolio. BPFE. Yogyakarta.
Trisnawati, N. K. D., \& Ni N. A. D. (2013). Analisis Pengaruh Reshuffle Kabinet Indonesia Bersatu Terhadap Harga Saham LQ45 di Bursa Efek Indonesia. EJurnal Manajemen Universitas Udayana, Vol. 2 No.10. Universitas Udayana, Denpasar Bali. 